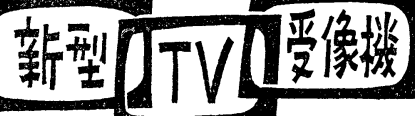

日立テレビ FMB-780 型

\section{4 吋テレビ受像機}

\section{日立慜作所戸塚工場 福 間 英 夫}

\section{設計製作方針}

本機は映像中間周波增幅 2 段であ るが，チューザ抢よび映像中間周波 增幅段の利得をなるべく大きくして 受信可能な範囲を拡げ，かつ音声回 路，水平発振 $\mathrm{AFC}$ 回路などは遠距 離型受像機と同様な性能を持ってい るので雑音の多い地区でも充分実用 になる点，さらに隣接チャネルの音 声信号比よる妨害除去用トラップを つけた点などが特徴である。従来映 像中間周波 2 段のものの中にはいわ ゆる簡易型受像機と称して種々興味 のある回路が使用されたるのがあっ たが，これらの受像機はその最高の 機能を持たせて大量に製作するこ と，いろいろな使用条件下で安定な 性能を長期にわたって保証すること などに非常な問題があり，これらの 点を考虑してこの FNB-780 型テレ ビ受像機は安定で実績のある回路を 使用し，遠隔制御器の取付けられる 構造にして将来の標準型受像機とな ることを目標にしたるのである。

\section{各部の詳細}

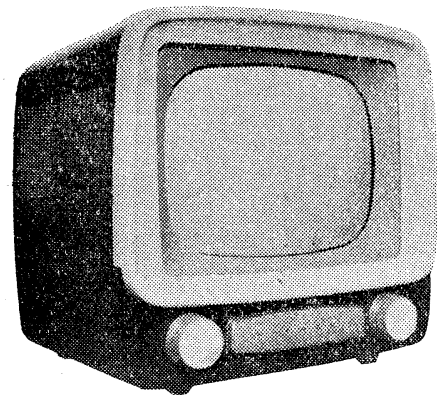

FMB-780 型14インチ受像機

$$
\text { (1) チューナ }
$$$$
\text { ロータリースイッチ方式による11 }
$$
チャネル受信可能のカスコード型チ ニーナである．前述のごとくこのテ レビ受像機は比較的近距離の聴視者 を対称に設計されたるのであるが， 感度上昇をはかったため電界強度 $200 \mu \mathrm{V} / \mathrm{m}$ 附近から実用になるので, 受像機の雑音指数が問題飞なり始め ることを考慮してカスコード型にし た。ロータリースイッチ方式にした 理由は，寿命試験によると口ータリ ースイッチ方式の方がターレット方 式より相当寿命が長かったことによ る. 主な特性は下記の通りである。

(a) 入カインピーダンス: 平衡 型 $300 \Omega$, 中心周波数に打汀る定在 波比 2 以下（第 1 図参照）

（b）带域特性（第 2 図参照）

(c) 利得: $33 \sim 35 \mathrm{~dB}$ ，第 1 f ヤネルと第11チャネルとの利得差は

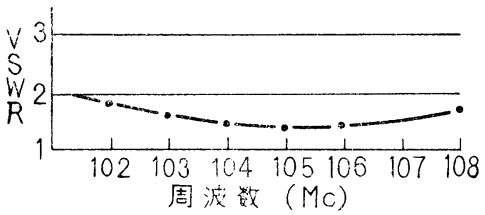

第1図（a）第3 チャネルの VSWR

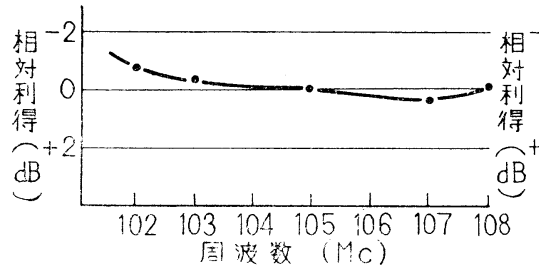

第 2 図（a）チューナの增幅特性 (第3キャネル)

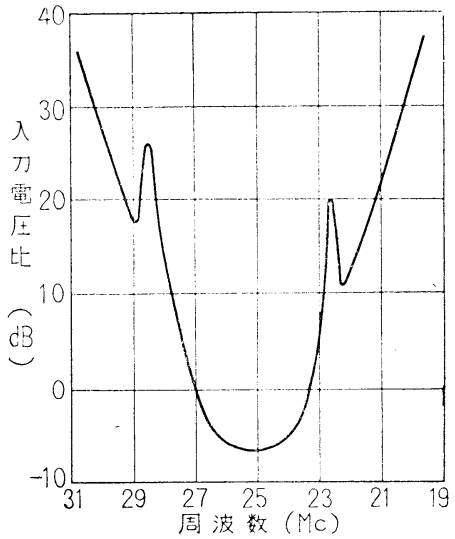

第3 図 映像中間周波增幅特性

約 $2 \mathrm{~dB}$ 以下である.

(d) 雑音指数：第 3 チャネルで $6 \mathrm{~dB}$ ，第 6 チャネルで $8 \mathrm{~dB}$ 以下で ある。

（2）映像中間周波增幅 高利得, 隣接チャネルの妨害除去, 良好な周波数特性(振幅, 位相特性) を考慮に入れて設計してある，振幅 位相両特性は密接な関係があり，ま た中間周波增幅の段数にもよるが一 応初期の目的を達成し, 解像力子良 好でスミヤ，またはオーバー・シュ 一トは局発周波数を変化しても目に つかない，映像中間周波增幅回路の 主な特性を下記に示す。

(a) 带域幅: $2.8 \mathrm{Mc} \sim 3 \mathrm{Mc}$ (第 3 図参照)

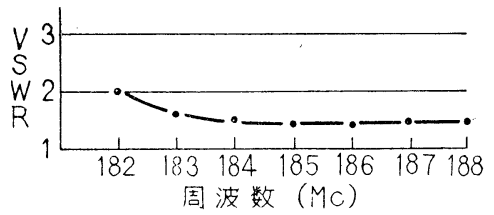

第 1 図（b）第 6 チャネルのVSWR

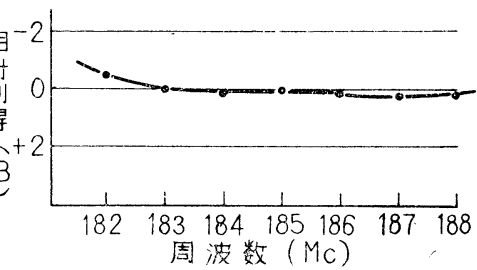

第 2 図 (b) チューナの增幅特性 (第6チャネル)

テレビジョン 


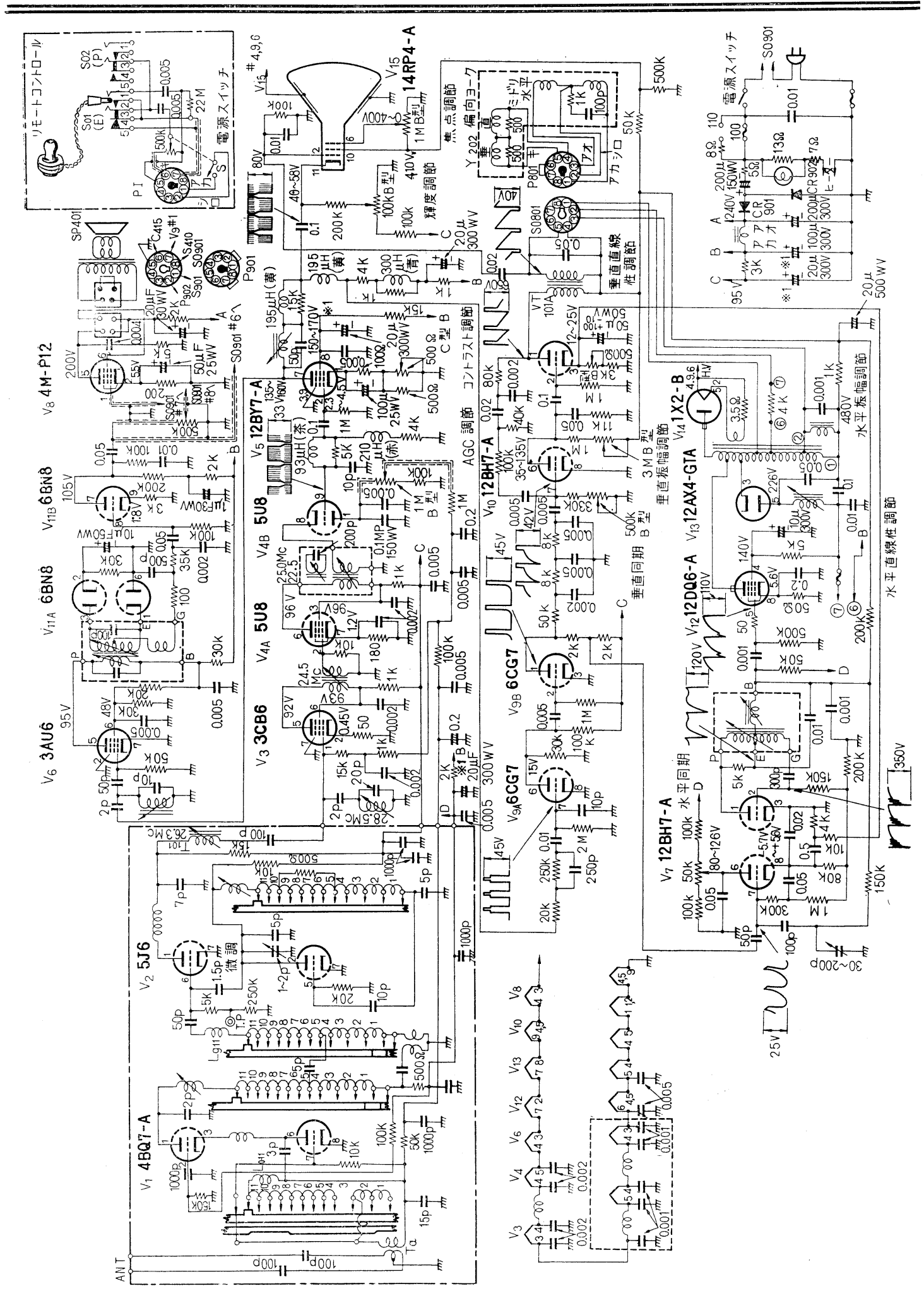

日立テレビ FMB-780 型 14インチ・テレビ受像機 


\section{新型 TV 受像機}

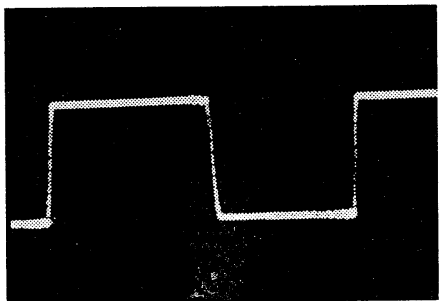

第 4 図映像増幅器のパルス増 幅特性 (人力パルス $100 \mathrm{kc}$ )

(b) 利得： $45 \mathrm{~dB}$ (検波器を含 屯)

(c) 隣接チャネルの音声トラッ プ付 (第 3 図参照)

(3) 映像増幅

12 BY 7-A により出力電圧の増 加, 音声信号と映像信号の混变調防 止等をはかり，負荷抵抗は比較的低 い $4 \mathrm{k} \Omega$ にして周波数特性の改良を 計った。ピーキングコイルおよびダ ンピング抵抗は図式計算および実験 により求めたものであって，第4 図 に示す通り良好な立上りでアンダー シュートあるいはリンギングなどの 欠点は全く認められなかった. 本回 路の仕様は下記の通りである.

(a) 利得 : $30 \sim 34 \mathrm{~dB}$

(b) 周波数特性：最大利得の状 態で $3 \mathrm{~dB}$ 減衰の帯域幅は $3.7 \mathrm{Mc}$

(c) コントラスト調整: $12 \mathrm{~dB}$ 可变

\section{（4）音声回路}

本回路は

(1) バズ音の出ないこと

(2)「ひずみ」の少いこと

(3) 遠隔制御装置によりテレビか ら離れたところでも音量調節電源接 断のできること

(4) 温度変化, 入力変動による特 性低下の生じないこと

などを目標に設計してある。

第 1 表 温度上年測定

\begin{tabular}{c|c}
\hline 温度上昇測定場所 & 温度上昇值 \\
\hline キャビネット上部 & $14^{\circ} \mathrm{C}$ \\
セレン整 流 器 & $24^{\circ} \mathrm{C}$ \\
シャーシ内 部 & $7^{\circ} \mathrm{C}$ \\
\hline
\end{tabular}

146
音声中間周波增幅管は振幅制限も 行い，各定数は広帯域ブラウン管オ シロスコープで最良点を測定して得 たものである。振幅抑制はまた比率 検波トランスの性能に大きく左右さ れるが，これは 1 次 2 次巻線間の結 合度和よび $Q$ によることを示す。 これらは実験により満足する值を得 た。音声関係の仕様は下記の通りで ある。

（a）振幅抑制作用括よび音声出 力特性 (第 5 図参照)

(b) 音声出力：無ひずみ最大 $1.5 \mathrm{~W}$

（5）同期回路および偏向回路 同期分離掞よび増幅回路では，同 期信号が映像信号によって位相变調 をうけないように回路る配置和よび 増幅帯域を決定した。垂直発振回路 は垂直出力管の陽極回路からの，フ イードバックによるマルチバイブレ 一タ方式を用いたが，このため予想 される困難な点，つまり水平出力の 混入によりインターレースが不完全 になる点と直線性の問題とに重点を おいた。これらは配置, 回路定数お よびその精度，使用部品，特に偏向 $\exists$ ヨ, 垂直出力管, 垂直出力ト ンスなどの実験的な検討により解決 した。水平発振管は $12 \mathrm{BH} 7-\mathrm{A}$ に より水平出力管 $12 \mathrm{DQ}$ 6-A に充分 な励振を与えた。本回路の仕様を下 記に示す。

(a) 水平同期信号出力：15 20 $\mathrm{V}$, パルス幅 $6 \mu_{\mathrm{S}}$ ，立上り抢よび立 下り時間 $1 \mu_{\mathrm{S}}$ 以下.

（b）偏向ひずみ：水平, 垂直共 $5 \%$ 以下.

(c) 高圧 : $10.5 \mathrm{kV} \pm 5 \%$ （ただ しビーム電流 $180 \mu \mathrm{A}$, ブースト回 路から $15 \mathrm{~mA}$ を取ったとき）

\section{その他}

本テレビ受像機は以上のような性 能を持つょうに設計製作されている が，この仕様に明記されていないい

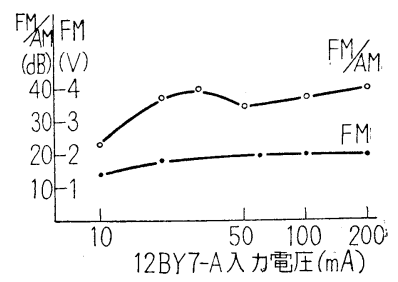

第5 図 音声 IF 検波特性

ろいろの点で努力が払われている. その例をあげると

(1) 部品配置を合理的にしてサー ビス上の便利をはかったこと

(2) 各部品の使用上の安全率を高 くとったこと

(3) セット自体の温度上昇を少く するように空気の流通に注意を払う ことはもちろん, 熱に比較的弱い部 品, すなわち電解蓄電器, セレン整 流器などの適当な配列などに苦心を 払ったこと

(4)震動衝撃試験をいろいろの角 度から行い，受像機の異常の有無を 調査したこと

等である.

受像機の温度上昇測定值を第 1 表 に示す.

また本テレビ受像機はトランスレ゙ ス方式を採用したので，カッラ材を 使用したダークブラウン仕上げの優 雅なキヤビネットと相まって軽量に なり取报上便利であるが，ヒータ回， 路により生ずる障害を絶無にすべく 実験を行った。

実験は真空管のヒータ接続順序は もちろんのこと敷線位置, 使用真空 管扣よび回路定数の適否にまで拈よ んだ.この結果電源周波数成分の混 入による画質の低下，動摇等は全く ない。

またパイロットランプで受信中の チャネル数字（ツマミの）のみを照 明する構造としたので，簡単で見や すいチャネル・インジヶータ付とな っている。

\section{is}

